Krzysztof Jurek (Łódź)

(iD) https://orcid.org/0000-0003-4904-7363

Jacek Kozieł (Łódź)

(iD) https://orcid.org/0000-0001-7232-4221

\title{
Byzantine Themes in Polish High School Liberal Arts Education
}

\section{Introduction}

$\mathrm{T}$ he question of Byzantine themes in liberal arts education is actually a question about Byzantine themes in contemporary Polish culture. These themes are not articulated explicitly. They constitute a part of the cultural heritage that is not discernible or - it might be better to say - not explained. It seems that for a considerable section of Polish society "Byzantium" is just an empty word. Thus - in our view - school education is crucial if this is to change as it is only at school that the vast majority of young people have the opportunity to learn history or Polish literature. In our opinion, these two fields of knowledge merit extensive analysis. We think that the term "Byzantium" in Polish history should be defined not simply in terms of the history of a political formation but also in terms of its cultural achievements. And this is primarily discernible in the history of the Orthodox Church, the Eastern branch of Christianity. At this point our deliberations are no longer purely historical but they bear on the present as people usually associate the Orthodox Church with Russia, an association which is absolutely erroneous. Consequently, the Orthodox faith is regarded as the religion of the foreign power that has had such a dramatic and damaging impact on Polish history. However, for a considerable period of Polish history nearly half the population of Poland was Orthodox. Accordingly, this means that the role played by the Orthodox faith in the history of Poland would make an excellent subject for another paper and provide an opportunity for us to broaden our knowledge of Byzantium. Alas, this is not the subject of the present paper.

The scope of a curriculum's contents is specified in the general syllabus prepared by the Ministry of National Education. This means that current curricula and relevant textbooks are developed on a common framework: the general syllabus. Whilst this might appear to be common knowledge, it strikes us that we 
sometimes need to be reminded of this. Furthermore, despite the huge freedom permitted curriculum and textbook authors, the general syllabus specifies a minimum teaching content that must be taken into account. The focus of our present deliberations is two school subjects - History and Polish. As regards the first, the matter seems obvious. In the curricula, the history of Byzantium is presented explicitly. Yet things are different in the Polish literature curricula. There, certain content is often concealed, for example in the selection of required set texts. Hence this knowledge is not transferred directly, which makes the examination of this theme even more challenging. This leads us to the question of precisely what knowledge students do acquire about Byzantium. In the section here devoted to Polish literature teaching, we took into account not only current curricula or syllabuses but we also considered literary works in which East-related issues appeared and which have appeared on the list of set texts at different times.

\section{History}

This school subject is described in detail in the general syllabus published for primary ${ }^{1}$ and high school ${ }^{2}$. As regards the primary school syllabus, the term "Byzantium" is mentioned only once: the syllabus content for grades IV-VIII includes Item II: "Byzantium and the Islamic World", where the student is expected to be able to 1) locate in time and space the extent of Arab expansion and explain the impact of the Muslim civilization on Europe; 2) locate in time and space the Byzantine Empire and demonstrate general knowledge of the Byzantine cultural achievement (law, architecture, arts) ${ }^{3}$. The themes in which we are particularly interested may also be found in the next item (Topic III "Medieval Europe", where the student [...] is expected to be able to 3) explain the causes and ramifications of The Great East-West Schism of the $11^{\text {th }}$ century, that divided Christianity, and describe relations between imperial and papal power; and 4) discuss the causes and ramifications of the Crusades) $)^{4}$. The themes are not articulated explicitly but it is obviously impossible to discuss these topics without them. Unfortunately, we are unable to say how these vague provisions translate into specific syllabuses and textbooks as the way in which the minister A. Zalewska implemented the education reform has prevented the timely preparation of textbooks.

The content of the general syllabus for high schools has been divided into elementary level and advanced level in the following way: Topic V "Byzantium

\footnotetext{
${ }^{1} \mathrm{https} / / /$ www.gov.pl/web/edukacja/podstawa-programowa-materialy-dla-nauczycieli2 [25 I 2019].

${ }^{2}$ http://www.dziennikustaw.gov.pl/DU/2018/467 [25 I 2019].

${ }^{3}$ Podstawa programowa kształcenia ogólnego z komentarzem. Szkoła podstawowa. Historia [General syllabus for comprehensive education supplemented with a commentary. Primary school. History], ed. W. SulEJA, https://www.gov.pl/web/edukacja/podstawa-programowa-materialy-dla-nauczycieli2 [25 I 2019].

${ }^{4}$ Ibidem.
} 
and the Islamic World", where the elementary-level student is expected to be able to locate in time and space the Byzantine Empire and demonstrate basic knowledge of its cultural achievements; 2) explain the genesis of Islam and know its principal tenets; 3 ) present the main directions of the Arab expansion; 4) describe the hallmarks of Arabic culture and know its most significant achievements. The advanced-level student, in addition to meeting the requirements specified for the elementary level, is expected to 1) describe the hallmarks of the Byzantine political system; 2) identify the stages of the Arabs' expansion and evaluate their policy towards vanquished peoples; 3) discuss the impact of Islamic civilization on the Latin and Byzantine civilization ${ }^{5}$. Furthermore, the Byzantine themes are also indirectly included in Topic VI "Europe in the Early Middle Ages" at elementary level, where the student is expected to be able to 3) describe a process state creation in Europe, including their Christianization (which was expressed more explicitly at advanced level); 2) describe a process of the founding of the first states in Central and Eastern Europe, including the impact of the Latin and Byzantine civilizations ${ }^{6}$. Another item touching on theme with which we are here concerned here is Topic VII "Europe during the Period of the Crusades", where the elementary-level student is expected to be able to 1) discuss the ideological and political causes as well as the nature of the competition between the papacy and the empire for control over Medieval Europe; 2) describe the political, socio-economic and religious determinants of the crusades to the Holy Land and the Reconquista, and list their ramifications. The advanced-level student is expected to meet requirements specified for elementary level, and further to this show her- or himself able to 1) explain the reasons for the Great East-West Schism of the $11^{\text {th }}$ century; 2) describe and evaluate the role the monastic orders played in Medieval Europe; 3) identify the directions, characteristics and ramifications of the Mongolian invasions of Europe ${ }^{7}$. Topic XI "Europe in the late Middle Ages", also includes a Byzantium-related theme. The student $[\ldots]$ is able to 3 ) describe the ramifications for Europe of the fall of the Byzantine Empire and Turkish expansion ${ }^{8}$.

This overview can be supplemented with some observations about a history textbook. Here we use one issued by the Nowa Era Publishing House, that which we the authors are most familiar with. Like other textbooks for the $1^{\text {st }}$ grade of the reformed high school, this will be available in summer 2019 as 1 September 2019 is the start of the school year, including for the reformed high school. The Nowa

\footnotetext{
${ }^{5}$ Rozporzadzenie Ministra Edukacji Narodowej z dnia 30 stycznia 2018 r. w sprawie podstawy programowej kształcenia ogólnego dla liceum ogólnokształcacego, technikum oraz branżowej szkoły II stopnia [National Education Minister regulation of 30 January 2018 on the general syllabus for the comprehensive education in high schools, vocational technical high schools and $2^{\text {nd }}$ degree vocational school (2-year course following $1^{\text {st }}$ degree 3-year course], http://www.dziennikustaw.gov.pl/DU/2018/467 [25 I 2019]. ${ }^{6}$ Ibidem.

${ }^{7}$ Ibidem.

${ }^{8}$ Ibidem.
} 
Era textbook permits us to draw a number of conclusions. Essentially, the history of Byzantium is mentioned three times: initially during discussion of the Eastern Roman Empire (Justinian the Great and his Code, an attempt to rebuild the Roman Empire, Hagia Sophia); next during discussion of the Crusades (primarily in relation to the reasons for the First Crusade, then also respecting the ramifications of the Fourth Crusade and the establishment of the Latin Empire); and lastly in association with the Turks' expansion and the capture of Constantinople. It warrants attention that the Byzantine-related theme usually appears in a Muslim context, initially with an Arab and later with a Turkish dimension. In this respect, the general syllabus topics are no different from those of the past: the extent of knowledge about Byzantium is the same. In short, the history of Byzantium lies on the margin of the margins in the system of Polish history education. It is sad to say but well-known that in Poland history teaching is not only Polo-, Roman Catholic- and Euro-centric but also based on a particular type of Occidentalism. Culturally, Poland is associated with Western Christianity. Yet in the past, Poland was a country composed of the two Christian religions: Catholicism and Orthodoxy. This fact is rarely foregrounded, but rather usually marginalized. Furthermore, Orthodox believers remain the second largest religious group in Poland. Accordingly, it is worthy of note that during history lessons Polish students do not learn about Orthodox believers in Catholic Poland.

\section{Polish}

In the teaching of both history and art history, Byzantium themes are named explicitly. It would be impossible to talk about Hagia Sophia (the Church of Holy Wisdom) and not say a word about the Eastern Roman Empire. After all, the "cathedral of cathedrals" is the most outstanding example of Byzantine architecture. Yet matters are very different when it comes to Polish literature teaching: unlike in the history curriculum, no specific topics relate to Byzantium. Students only learn about this empire in the context of other issues. Consequently, students remain unaware of Polish association with Byzantium and Eastern Christianity more generally, and teachers too are often similarly uninformed.

This is perfectly exemplified by Bogurodzica (lit. trans. God-bearer), a text composed by an unknown author. Bogurodzica has long been discussed in Polish schools as one of the most significant Polish literary works, and named a carmen patriae. One of the foremost experts on Polish literature, Maria Janion, considers this song about the motherland to be an unforgettable testimony of EasternWestern Slavdom ${ }^{9}$. Other scholars concur. In the 1930s the relationship between Bogurodzica and the Byzantine Deesis icon was underscored. The latter depicts a centrally positioned Christ flanked by the Virgin Mary to his right and John the

\footnotetext{
${ }^{9}$ M. JAnion, Niesamowita słowiańszczyzna, Kraków 2016, p. 183.
} 
Baptist to his left ${ }^{10}$. The structure of Bogurodzica resembles a kontakion, a Greek hymn, particularly the Western variant that developed in Italy between $9^{\text {th }}$ and $11^{\text {th }}$ centuries. And this leads us to the issue of Eastern and Western influences on Polish culture. Despite their differences, at the beginning of its second millennium, the heritage of Eastern and Western Christianity remained unfractured, which means that Byzantine influences were also able to reach Poland indirectly, from Italy, a country recognized as Western. The Bogurodzica contains Greek words. Thus, the connection between the oldest work of Polish literature and Byzantine culture is quite clear. Yet the issue at stake is whether teachers realize that this is a remarkable example of the presence of Byzantine themes in Polish literature and whether they highlight this aspect during lessons. In our view, this rarely happens.

Romanticism is the literary period where clear Byzantine connotations are mentioned and discussed during Polish lessons. They are, however, utterly negative. This is because Byzantine traces take the form of Russia, a country and culture that comes to epitomize all that is evil, the major perpetrator of the partitions of Poland and its related misfortunes. Such a depiction is particularly visible in the literary works of Adam Mickiewicz, Juliusz Słowacki and Zygmunt Krasiński, although the latter author presents it in a more systemized manner. The most significant works analyzed at school primarily consist of those by Mickiewicz - Part III of Dziady [Forefathers' Eve], Pan Tadeusz [Mr Thaddeus] and Reduta Ordona [Ordon's Redoubt] - and by Słowacki, the play Kordian.

Dziady depicts the oppression suffered by the Poles prior to the outbreak of November Uprising. The East, which is Russia, epitomizes despotism, rule based on fear of the tsar and high-rank officials along with their ruthless attitude towards those of a lower rank. It is this that is staged in the much-discussed Scene 5 of the play (the senator's dream) as well as the poems included in The Passage (the prologue to the play). Russia is featured there as a callous country devoid of feeling. The picture of its capital, featured in the poem Petersburg, is terrifying - the place is gloomy and permeated with fear. In a similar fashion, the poem Przeglad wojska [Inspection of the Troops] features the tsarist system of governance. The poem's author warns representatives in the West against superficial admiration for Russian civilization that might lead to acquiescence to the tsars' state. Those inhabiting this state are pictured as an immature people who - when freedom eventually comes - will turn either into a bright butterfly that will fly into the sky or a moth - a dirty night tribe. In the play's main scene, Great Improvisation, Konrad, the hero, is not damned only because in his dispute with God he did not blaspheme, that is compare Him to the tsar, simply because he had too little time. Everything is expressed in crude language using expressions such as the tsarist scum. A similar image appears in Reduta Ordona and, although less crudely, in Pan Tadeusz too. The same picture of the East can be seen Kordian, by Juliusz Słowacki, which has

${ }^{10}$ Ibidem. 
been a set text in school for decades. The beginning of Act 3 and the conversation between the Tsar and Great Prince in that same Act, reveal how the system of despotism works, while Scene 4, which stages the meeting of the conspirators, depicts Moscow's cruel policy towards the Poles as well as their determination to fight for freedom.

As regards set texts from the later $19^{\text {th }}$ century, the period of Positivism, the Byzantine theme is only to be found in Ogniem i mieczem [With Fire and Sword] by Henryk Sienkiewicz, a historical novel about the Cossack uprising that broke out in the mid- $17^{\text {th }}$ century. At present, the book is no longer a set text in schools but formerly it was on the recommended reading list, which meant that teachers could chose to analyze it in Polish lessons. Yet it has always been part of the cultural awareness of Poles and we hope that it will long remain so. The book is worth attention as the themes associated with Eastern Christianity are well defined there. It is worth noting that they are not featured as one-sidedly as in Romantic literature. Contrary to opinion commonly presented in Polish writing, Henryk Sienkiewicz, a historian by profession, shows the reasons for the outbreak of the Khmelnitsky Uprising to be complex, and to a large extent the result of the unwise policy the Polish aristocracy and noblemen adopted in relation to the Cossacks, which was actually a form of economic oppression. Sienkiewicz emphasizes that cultural and religious division into Poles and Ruthenians, Catholics and Orthodox was not clear cut. The Polish "camp" included a large number of Ruthenians who proudly displayed their affiliation with the world of Eastern Christianity. They included above all the voivode Adam Kisiel, who desperately attempted to establish peace between the feuding parties, aware that the Polish-Cossack war primarily benefitted the enemies of the Republic of Poland. Ruthenians were also found among the officers and soldiers serving Prince Jeremi Wiśniowiecki, who pursued a cruel and uncompromising war against insurgents. In fact, the prince came from an old Ruthenian family and only his father converted to Catholicism, like many other representatives of the Ruthenian aristocracy. A large number of the novel's protagonists, from Princess Helena Kurcewiczówna and Cossack Colonel Bohun onwards, are Ruthenians.

Fyodor Dostoyevsky's Crime and Punishment holds a special place in Polish schools. For years it has been discussed in Polish literature lessons, and the school interpretation takes into account the novel's religious plot, Sonia's steadfast faith and the role her belief plays in the repentance and moral transformation of the main protagonist, Rodion Raskolnikov. The positive influence of Russian Orthodoxy is difficult to omit from a school reading of this novel, although there is no doubt that this feature is often paid insufficient attention.

For a short period of time (1990s), the list of recommended set texts included Krzyżowcy [Crusaders], an excellent historical novel authored by Zofia Kossak, 
which deals with the history of the first Crusade. Unlike the aforementioned literary works, where it was quite difficult to find any Byzantine-related themes, here they are extensively discussed. This is a text in which readers discover quite a lot about the late $11^{\text {th }}$ century history of Byzantium. Kossak details Byzantine diplomats' successful efforts to convince Europeans to embrace the idea of the Crusades. Readers learn about the imperial court, how it was organized, as well as the difficult relations between Crusaders and Byzantines. Unfortunately, in the aftermath of another education reform, this novel by Kossak was removed from the list of obligatory set texts and recommended readings and it will certainly be not reinstated... Likewise, the work of the outstanding poet Jerzy Harasymowicz, which alludes to the Ruthenian, Greek Catholic traditions, texts which teachers discussed in Polish literature lessons during the 1970s and 1980s.

\section{Conclusion}

The account presented above clearly shows that Byzantine themes form only a very small part of the high-school syllabus in Poland. In our view, this is definitely insufficient and needs be changed. The cultural identity of modern Europe rests on three foundations: the West, the East and the Arab civilization. Yet the syllabus is focused almost exclusively on the first of these. It is probably no exaggeration to say that, paradoxically, students learn more about Islam than Eastern Christianity, even though this has had an incomparably greater impact on us. It is difficult not to get the impression that a narrowly defined "Polish Westernism" has had a negative impact on our knowledge about the origins of our culture.

We have no intention to call for any profound changes in the liberal arts syllabuses. We just want to highlight the current low level of awareness among the Polish people of one of the most crucial elements of the European heritage. The fact that a similar situation has also been observed in other countries should in no way be any consolation. This is clearly proved by what Judith Herrin, an outstanding British expert in Byzantine studies said in the introduction to her book promoting the history of the empire that ceased to exist nearly 600 years age: One afternoon in 2002, two workmen knocked at my office door in King's College, London. They were doing repairs [...] and had often passed my door with its notice: 'Professor of Byzantine History. Together they decided to stop by and ask me, 'What is Byzantine History?' They thought it had something to do with Turkey ${ }^{11}$. It may be some comfort that they were at least able to correctly match the term with a geographical region. Would Polish workers be able to do this too?

${ }^{11}$ J. Herrin, Byzantium. The Surprising Life of a Medieval Empire, Harmondsworth 2008. 


\title{
Bibliography
}

Herrin J., Byzantium. The Surprising Life of a Medieval Empire, Harmondsworth 2008.

Janion M., Niesamowita słowiańszczyzna, Kraków 2016.

Podstawa programowa kształcenia ogólnego z komentarzem. Szkoła podstawowa. Historia [General syllabus for comprehensive education supplemented with a commentary. Primary school. History], ed. W. SulEJA, https://www.gov.pl/web/edukacja/podstawa-programowa-materialy-dla-nauczycieli2 [25 I 2019].

Rozporzadzenie Ministra Edukacji Narodowej z dnia 30 stycznia 2018 r. w sprawie podstawy programowej kształcenia ogólnego dla liceum ogólnokształcącego, technikum oraz branżowej szkoły II stopnia [National Education Minister regulation of 30 January 2018 on the general syllabus for the comprehensive education in high schools, vocational technical high schools and $2^{\text {nd }}$ degree vocational school (2-year course following $1^{\text {st }}$ degree 3-year course)], http://www.dziennikustaw.gov.pl/ DU/2018/467 [25 I 2019].

\begin{abstract}
The authors focus how Byzantine motifs are presented in the teaching of humanities subjects. The question of the presence of Byzantine motifs is essentially one about the presence of Byzantine heritage in Polish culture. With reference to two school subjects - Polish and History - the authors seek to establish what Polish school students are taught about the reach of Byzantine culture.

Present-day teaching of both political and cultural history is underpinned by Occidentalism. Only occasionally is attention paid to the "Eastern" features of Poland's past. A good example of this is the treatment of one of the most important Polish literary texts, the school perennial, Bogurodzica. This draws on Greek religious hymns, contain words originating in the Greek liturgy, and also alludes to a particular type of icon. Accordingly, the connections between the oldest Polish literary text and Byzantine culture are very clear. However, when classroom teachers discuss Bogurodzica with their pupils, detailing the above-mentioned features, are they aware that this text is an epitome of the presence of Byzantine motifs in Polish literature? Apparently not.

With regard to the teaching of history, Byzantine motifs can be approached from at least three angles; in terms of imperial political events, in terms of religious (Eastern rite) aspects of Byzantine culture, and finally in terms of awareness of connections between Polish culture and Eastern rite Christianity, as well as Eastern nations and states viewed as heirs of Byzantine culture.

In Polish history there has been a side-lining of the nation's break with Eastern Christianity even though during certain periods this was the faith of half the Commonwealth's inhabitants. The marginalisation of this topic does not simply impose a limit on knowledge but it prevents the understanding of particular aspects of our history.
\end{abstract}

Keywords: Byzantium, national curriculum, teaching history, Byzantine motifs.

Krzysztof Jurek

krzysztofjurek@wp.pl

Jacek Koziel

jackoziel@poczta.onet.pl 